\title{
Izmir Craft Beer Trail
}

\author{
Pinar İsildar ${ }^{1, *}$, Ozay Yildiz ${ }^{2}$ \\ ${ }^{1}$ Department of Gastronomy and Culinary Arts, Reha Midilli Foça Faculty of Tourism, Dokuz Eylul University, Turkey \\ ${ }^{2}$ Department of Tourism Managemen, Reha Midilli Foça Faculty of Tourism, Dokuz Eylul University, Turkey
}

Received December 9, 2019; Revised April 22, 2020; Accepted May 13, 2020

Copyright $@ 2020$ by authors, all rights reserved. Authors agree that this article remains permanently open access under the terms of the Creative Commons Attribution License 4.0 International License

\begin{abstract}
Craft beer tourism is a type of special interest tourism, which is increasing in popularity in parallel with the growing interest and curiosity for novel, experimental, small-scale and artisan types of beer and related themes. As such, trails are gaining popularity, which integrate the opportunities to explore new tastes, methods of production and experimentation around craft beer and also complementing elements of food pairings, stories and heritage, shopping, places and landscapes around craft beer. These trails offer a more complete tourism product as well as a stronger sense of place, memorable tourist experiences and therefore opportunities for destination branding and overall promotion. In this context, an explorative field research has been conducted, possible participants have been identified and interviewed. As a result, the model for a craft beer trail in Izmir has been proposed and mapped, to include the places that produce and serve craft beer and related products, urban landmarks, accommodation and transportation, and a scheme for its management is presented. The trail is proposed to embrace and promote the natural and cultural landscape, social life, craft beer related and general cultural heritage and overall tourism attraction of Izmir, ultimately branding the city as a prominent craft beer destination. Additionally, the trail should provide product diversification as well as a means to increase occupancy rates and ease tourism congestion.
\end{abstract}

Keywords Craft Beer Trail, Beer Tourism, Local Gastronomy

\section{Introduction}

Beer is very probably the oldest, but definitely the most popular alcoholic beverage, accounting for no less than $78 \%$ of the total alcoholic beverage production worldwide, clearly indicating its economic importance [19,50]. With total volume of production close to 2 billion hectolitres in 2017, the market is strongly dominated by Belgian based (multinational) Anheuser-Busch InBev (ABI), after their acquisition of SABMiller in 2016, accounting for a hefty 31,4\% market share. The top 5 companies (ABI, Heineken, China Res. Snow Breweries, Carlsberg \& Molson-Coors) produced $60 \%$ of the total volume worldwide in 2017 [50].

Despite the clear market domination of large corporations, there has been an evident trend towards independent, small-scale and craft beer production as well as emerging beer producing countries. The rise of small-scale craft beer production has been hailed as a "Beer Renaissance", with producers focusing more on flavour and brewing techniques, rather than total output volume [38].

Another observation is the move away from mass produced lager style, which has been dominating the industry for the last few centuries. Especially the last decades saw a growing interest towards different styles, small-scale, local and quality products, novel tastes and aromas. As a result, craft beer rose to prominence [35]. As the production of craft beer is steadily increasing, it has begun to cut into the market share of the large corporations, accounting for $2.5 \%$ of total world beer production. This trend has not gone unnoticed by larger corporations who have been acquiring craft labels, such as Japanese Sapporo acquiring the legendary Anchor Steam Beer of San Francisco [50].

Craft brewing started as a micro-brewing movement, predominantly in the UK, in the late 1970's, and flourished in the United States in the 1990's [38]. Emerging as an alternative to mainstream beer in its early years [14], it is now a well-established product in the USA and is especially appreciated by the "millennials", a segment of approximately 70 million consumers composed of youths aged between 21 and 30 who might contribute to the growth of this market segment, representing $6 \%$ of the total market volume [6].

Following its emergence in the seventies, craft beer has extended worldwide in first decade of $21^{\text {st }}$ century [38]. In Mexico, consumption of craft beer has seen a steady, double digit increase and now accounts for a litre per 975 litre of total beer consumed [19]. In Europe, especially in 
Italy, craft beer is increasingly consumed by frequent beer drinkers in pubs or at home with their families. A relevant study reflected Italian beer consumers' perception of craft beer as a high standard, quality product, favoured especially for its variety of flavours and aromas, contrasting straightforward commercial brands [5]. Likewise, French consumers, due to a growing interest in discovering authentic tastes and supporting local entities, are increasingly interested in craft beers. Small breweries in France currently enjoy a growing regional popularity and it is observed that the number of small breweries is on the rise ( $+13 \%$ annually) [19]. An increasing number of U.S. consumers express their preference for taste and individuality through their choice of purchasing alternative beers [14].

This research first aims at an overall analysis of craft beer as the main attraction of travel; craft beer tourism as a clearly defined type of tourism product. A typical manifestation of craft beer is a trail not unlike in wine tourism and thus the present paper aims to examine the potential craft beer tourism product by focusing on the production and service of craft beer and to propose a craft beer trail in Izmir, Turkey. In order to achieve these aims, the study adopts a qualitative research method and the research design is exploratory.

\section{Craft Beer Tourism}

Craft brewing is defined as brewing largely by traditional methods and ingredients by independent (commercial) breweries, with a shared goal of brewing beer with superior flavours and character, compared to larger corporations: "boldly flavoured beers coupled with a defiantly independent spirit” [38]. Although there is a lack of a universal classification of craft beer, the emphasis is on artisanal and traditional brewing techniques, quality local ingredients and experimentation, rather than a simplistic limitation of production volume. Another characteristic is the refusal of macro-brewing methods in favour of a "DIY approach", resulting in unique products that reflect the brewers' and / or production regions' authenticity, meaning and story [28]. This also results in craft beer turning into a tourist attraction / product, giving craft beer connoisseurs a reason to travel.

By definition, "two variables distinguish / define craft beer: the type of beer and the size of the production facility. As to the style, craft beer can mean different varieties of beer - ale, stout, porter, even lager - but never brewed with adjuncts or artificial ingredients" [18].

"(A craft brewery) includes any small, independently owned brewery that adheres to traditional brewing practices and ingredients. Craft brewers are distinct from larger regional and national breweries, which often use non-traditional ingredients and brew on a much vaster scale" [1].
Brewers Association, the trade group for craft breweries in the USA, has been opting to devise clear indications of (national) classification for brewing. By definition, a craft brewery's volume of production is defined as small: less than 6 million barrels (715 million litres). Furthermore, a craft brewery should be small, independent and traditional. Independent means that "less than $25 \%$ of the craft brewery is owned or controlled by a beverage alcohol industry member who is not a craft brewer" and traditional means that "a brewer that has a majority of their total beverage alcohol volume in beers whose flavour derives from traditional or innovative brewing ingredients and their fermentation" [9]. Craft beer also refers to a focus on beers that are made entirely or mostly from malt, and not diluted with adjuncts like corn or rice [18].

Brewers Association further subdivides small scale segment into four types of operations; microbreweries, brewpubs, contract brewing companies, regional (craft) breweries, all classified according to their volume of (and approach to) beer production and sales [6]. Note that the Association encompasses these brewery practices under the term "craft beer industry". Likewise, the term "craft beer" is meant to refer to all types of small scale, boutique, micro, artisan etc. approaches to brewing.

Craft beer is generally a non-filtered and unpasteurized product unlike industrial beers. The absence of microfiltration and pasteurization in craft beer brewing allows that the yeast remains in the product, hereby providing the craft beer remaining "alive" and evolving over time through secondary fermentation in bottle [23]. Another defining factor of craft brewing is the heavy use of and experimentation with hops, to attain striking and different tastes, aromas and levels of bitterness (IBU). As noted, craft beer accounts for 2,5\% of total beer market worldwide while consuming no less than $25 \%$ of total hops [50].

The parameters usually monitored in craft beer production during fermentation are the $\mathrm{pH}$ and soluble solids content (SSC) or optical density (OD). Another often controlled parameter is the number of cells in suspension (dry cell weight, DCW) [3, 30, 32, 34,]. Bitterness units (IBU), ethanol content, EBC (European Brewing Convention) colour and lactic acid are other factors used to control beer production $[7,30]$.

The non-existence of complicated control and standardisation mechanisms may result in different, unforeseen, wild and unique products, which become sought-after rarities. Problems related to small-scale production may be offset by the high price of craft beers and variability in the quality level of craft beer. Passion and effectiveness shown by many craft breweries attract a growing number of people who have become keen on craft beer contributing to its growth. An emphasis on local ingredients as well as limited pasteurisation / filtration result in unaltered sensorial characteristics [23].

Factors related to the purchase process (such as branding) 
have been found to be equally important as the attributes of the beer in the purchasing decision [5]. Taste attributes in beer have been widely studied. Allison \& Uhl [2] fifty years ago found that consumers were unable to recognize beer by taste while their choice was often influenced by information received about brands. Consumers were buying branded beer not by the taste, but personal effects of the properties they perceive and the effect of the brand image.

In a recent exploratory study, Aquilani et al. [5] found that craft beer is chosen for its variety of flavours. In their study, they found out that "malted barley, chestnut and honey-flavoured beers increase the probability of perceiving craft beer to have a higher quality than commercial beer”. Choi \& Stack [14] found that consumers choose alternative beers, "to express their preference for taste and individuality”.

Factors related to the purchasing process are also studied, just as extensively in literature. Factors including nutritional components, price, brand, distribution, differentiation and packaging are mostly studied in literature to discover the influence on beer consumption choice. Various works [31, 46, 47, 55] have all concluded that nutritional components and nutritional information of beer affect consumer decision making. Moreover, in the study of Caporale \& Monteleone [13] on organic beer showed that, preference of organic beer depends on consumer awareness on naturalness and its positive effects on consumer health and environment.

Kleban \& Nickerson [29] define craft beer as the driver of the "taste revolution". To produce craft beers, traditional methods are used in combination with unique formulas which add non-traditional ingredients. According to them, the success of craft beer depends on "beer quality, availability in the marketplace, competitive pricing, marketing and promotions". Clemons et al. [15] add to these factors hyper-differentiation opportunities and effects.

As tourist demand is concerned, in parallel with the shift in consumer demand toward highly regional products, like seasonal produce, local honeys and heritage grains, the integration of elements coming from the regional beer production are directing the interest of beer lovers to craft beers [8]. Research on and travel to craft beer regions have been increasing, because of factors including the discovery of new flavours, the search for quality, the curiosity of beer workmanship and the curiosity of local delicacies and places. Craft beers are attracting beer lovers' interest by offering different flavours, and this encourages tasting travels. It is thought that craft beer is also effective as a differentiating tool, especially in the coastal cities [38], such as Izmir.

In defining craft beer tourism, though, classification of tourism related activities has always lacked clear-cut boundaries and guidelines, due to the very nature of tourism: dynamism, changing market expectations, overlapping activities etc. Leaving broad "forms of tourism" devised for statistical purposes aside, UNWTO uses the term "types of tourism product" to refer to a more specific sense. These represent common specific aspects around the activities, destinations and centres of interest. A "tourism product" is however is meant mainly for marketing purposes, not for economic statistics, and "are still not sufficiently characterised in a uniform way" [52]. Traditionally, main source of motivation, or main attraction should be considered when classifying tourism activities.

Beer tourism then, as a type of tourism product, refers to "various tourist activities around the main attraction of beer as a commodity or idea", and has widely been studied under culinary/gourmet/food (and beverage) tourism [4, 16, 17, 36, 37, 40]. Being a distinct type of special interest tourism [27], beer tourism is also widely referred as a niche in the overall market [4, 17, 36, 37, 41, 43, 54]. However, contrasting approaches to niche classification do exist; Wesson \& de Figueiredo [54] argue that the segment is still in infancy and entrepreneurship approaches vary greatly, "serving a broad cross-section of the market". Another research on North Carolina beer tourists failed to determine a distinct niche profile [21].

Beer tourism has also been widely researched in comparison with similar beverage-oriented forms of tourism, including wine, coffee, tea, sake, whisky, bourbon or brandy tourism. Wine tourism in particular, being a more established and studied subject, emerges as a main source of foundation: "a form of special-interest travel based on the desire to visit wine-producing regions or in which travellers are induced to visit wine-producing regions and wineries in particular, while traveling for other reasons" [10]. However, beer tourism differs from its wine counterpart in specific ways. Mainly, wine production relates to a great extent to agricultural production, and therefore visitation of a wine production region means the visitation of vineyards, giving wine tourism a heavy rural / agricultural tourism inclination, with significant environmental sustainability implications. However, "beer production is not necessarily tied to where grains and hops are produced”, and the brewery is not necessarily rural, differentiating beer tourism, where the brewing methods and especially its linkages to the host community appear as the main attractions [41], therefore lending it more of a heritage / cultural tourism inclination with more of socio-cultural sustainability implications [10,36]. On a separate note, beer tourists have been found to be younger and more male-dominant than wine tourists, but the result is far from conclusive. [21, 41].

Beer tourism is defined as "visitation to breweries, beer festivals and beer shows for which beer tasting and experiencing the attributes of beer region are the prime motivating factors for visitors" [41]. The attraction factors may be closely linked to the beer as a commodity; appreciation of the nuances of beer flavour, texture and 
character, its story, as a component of urban life, arts, nightlife and of course, food [37]. A second form of attraction includes places or events related to beer, such as the visitation of breweries, pubs, beer gardens and museums, and any beer-themed special event, including Oktoberfest, Toronto's Festival of Beers etc. [41].

\subsection{Craft Beer Trail}

Defining craft beer tourism within the scope of beer tourism or a micro-niche [42] within a special interest tourism product [27] may be misleading. While the overall attraction factor in non-craft beer tourism weighs towards visitations of factories or museums and attending beer related events and where beer most often plays a supporting role, craft beer tourism includes purposeful exploration of and / or meeting with lesser known producers and beer tasting, visitation of local pubs, craft beer related landmarks, regions and trails $[37,41]$. As such, craft beer becomes a main attraction and a source of motivation for the dedicated beer tourist; rather than a niche within a niche.

"Craft Beer is big business in America with a proven ability engage a new travel consumer who will spend added dollars to visit local neighbourhoods and beer-themed events" [37]. "Craft-beer sector represents a niche market, also using locally brewed craft beer in combination with food as drawing cards that may additionally lead to the development of beer tourism in the state [4]. Craft breweries have the ability to offer premium quality experiential tourism services as part of their product offering” [17].

Another important aspect of craft beer tourism is the strong relationship with the local culture; craft beer most often represents uniqueness, authenticity and locality [54] (as is the case in wine tourism), where brewing methods, ties with local communities and traditions, local heritage and history, stories, landmark breweries and pubs as well as local cuisine complement the main attraction $[37,41,44,45]$. This presents craft beer tourism as a contributor of social and environmental sustainability [10].

Besides the obvious benefit of a direct sales channel [10] and increase in sales volumes [54], craft beer tourism may encourage green [33] or organic [10] forms of production, and may strengthen local identity [36] to enhance a destination's image [4] by increasing occupancy rates and benefiting the overall local economy [37]. Such an approach enables craft beer to fulfil its function of boosting local economic development through "maximising economic and social leverage between the tourism industry and producers, reducing economic leakages and adding value" [26].

"The breweries are farming out their ingredients locally. Local ingredients can add to the quality and distinction of a beer. (...) What's more, the microbrewery movement is also a geographic manifestation of anti-globalization sentiment" [45].

A “beer trail”, similar to a "wine route” [48], is any form of formal or informal amalgamation of beer - related attractions, producing a more complete tourism product, offering more memorable tourism experiences and benefits for the entire region, resulting in a beer (or food) related destination image: "the large production and variety of locally grown foods, the many offerings in terms of outdoor activities, and the varied landscape could be combined to develop a more 'complete' tourism offering" [4].

Through the literature on beer trails, "collaboration" emerges as a recurring keyword [4, 17, 41]. As with any case of a "voluntary arrangement" [24], partnership [41] or "strategic alliance” [48], a beer trail requires collaborative relationships of small-scale beer producers within a defined region [4], implying that the idea of a beer trail is predominantly craft beer related. A craft beer trail also requires joint promotion, as well as the networking and synergistic increase of the region's brewing related social capital [11, 26, 39, 49]. This is also reflected in (predominantly) non-monetary motives of craft beer enterprise, including "passion for brewing”, "inspiration", "sharing of technical information" and producing "new, flavourful, gourmet, innovative, fresh (...) beer” [4, 22]. A beer trail naturally would include vertical links in addition to horizontal ones [11], inviting the whole local economy to participate in value creation, in order to produce a wholesome tourism product.

Examples of craft beer trail or similar initiatives include "Visit Tampa Bay", an ambitious online promotional campaign that resulted in an additional 11000 overnight stays [37], also trails in the states of Washington, Oregon, Colorado [20] and Pennsylvania, Finger Lakes Beer Trail in New York and Bend "Beer Town” [56]. The best documented initiative was probably the "WaterlooWellington Ale Trail”, a self-guided tour of six craft breweries (using natural ingredients and traditional methods), which became the primary attraction of the region, besides increasing awareness and consumption of local brands. The trail initiated non-profit organisations with specific functions, including a planning committee and "Waterloo-Wellington Area Brewers Group", whose objectives included "establishing the area as one of brewing expertise, instilling pride in regional breweries, attracting visitors to the area and to individual breweries, developing a network of partners in the related hospitality industry, develop partnerships for tourism promotion, and selling more beer" [41].

Maintaining collaborative initiatives also proves to be troublesome. Dynamics of networks and interdependency [39], formal and informal agreements [48], maintaining coherence while managing conflict [11], industry conditions, differing individual managerial focus and resulting competition over joint competitive advantage [54], maintaining individual independence and autonomy 
as well as issues of trust, conflicts of time, commitment, goals, beneficiaries and decision-making [53], inter-organisational relationships and competing interests [40] include some of the challenges in maintaining such collaborations.

Consequently, the Waterloo-Wellington Ale Trail collapsed as breweries left the initiative due to lack of commitment, dissatisfaction as well as economic decisions including expansion [40].

\subsection{The Case of Izmir}

Izmir is the $3^{\text {rd }}$ most populated city in Turkey. It is located at the Aegean coast and the city centre is spread around the Izmir Bay. Izmir is a prominent destination in Turkey, with a total bed capacity of around 50,000 (registered by the Ministry of Culture and Tourism). The city accommodated around 3.8 million tourists in 2018 [51]. The city also boasts a vibrant night life, both in the city centre and numerous coastal towns, which are also important destinations of coastal \& recreational tourism.

The city demographics are quite accommodating for the public consumption of alcohol and related events. The main event that is determined to be focal for the present research, $3^{\text {rd }}$ "Brewstival" is an annual nationwide craft beer festival, was held on April 28, 2019 in Izmir Arena. The festival is a celebration of home and craft brewing, beer culture, music and related entertainment. In 2019, 6 national commercial craft breweries and numerous non-commercial homebrewers participated the festival. The events included workshops on homebrewing, beer cocktails, tasting methods and food pairings, as well as seminars on beer history, a homebrewing contest, a stand-up show, recreational contests, concerts and food and souvenir stalls. During the preparation of the paper, a second beer-themed event, "Eats and Beats Oktoberfest", to be held at 5-6 October 2019, was announced. This further proves the city to be an appropriate choice for an eventual beer related trail.

\section{Methodology}

The main purpose of the research is to examine the potential craft beer tourism product by focusing on the production and service of craft beer and to create a craft beer trail in Izmir, Turkey. In order to achieve these aims, the study adopts a qualitative research method and the research design is exploratory. The field research encompasses semi-structured interview and participant observation technique as methods of information gathering.

The population of the research consists of festival participants, craft beer producers, brewpubs, bars, restaurants, where craft beer is produced and / or served, or where craft beer may play a supporting role for tourism in Izmir. During the $3^{\text {rd }}$ "Brewstival", a total of 39 face-to-face interviews were held, including 23 professionals (16 homebrewers, 6 craft brewers, 1 beer expert) and 16 festival participants, that contribute to the celebration, recognition and development of craft beer in Izmir. Interviews lasted approximately from 5 to 15 minutes. The authors participated in the festival all day and observed the attitudes of people about craft beer. The interviews were structured and designed in order to explore how a craft beer trail, as a tourist product, should be formulated and which stops it should include.

Afterwards, the defined stops themselves were visited and an in-depth interview was held with a relevant person at each of the 7 stops, in order to find out their willingness to participate to such a trail, its management and promotion, as well as their approach on its potential contribution to tourism in Izmir. These interviews lasted from half an hour to an hour and resulted at 46 interviews in total.

Semi-structured interview technique was utilised as the data gathering method and the interviews consisted of open-ended questions, based on the literature and similar examples of craft beer trails reviewed. Descriptive analysis was used to analyse data in this study. In first stage of data analysis, the qualitative data obtained from the interviews was transcribed from sound recorders to a written sheet. In the second stage, researchers analysed the respondents' statements interpretatively regarding the formation and structure of the trail, as a tourist product that would attract both domestic and inbound visitors.

\subsection{Findings}

The findings were partitioned on three separate groups, based on the result of the views expressed by the festival participants, professionals and the stops. The demographics of all the interviewees are given in Table 1 below:

Table 1. Summary of demographic characteristics

\begin{tabular}{|c|c|c|c|c|c|c|}
\hline & \multicolumn{3}{|c|}{ Gender } & \multicolumn{4}{c|}{ Age } \\
\hline & Female & Male & $20-30$ & $30-40$ & $40-50$ & $50+$ \\
\hline Festival participants & 8 & 8 & 10 & 5 & 1 & 0 \\
\hline Professionals & 7 & 16 & 2 & 15 & 5 & 1 \\
\hline Trail stops & 2 & 5 & 0 & 5 & 2 & 0 \\
\hline
\end{tabular}


The festival participants expressed a unanimous acceptance of and enthusiasm for the proposed craft beer trail. The majority declared a demand for craft beer and a preference for pubs that serve local and craft beer brands. They also expressed their delight on the developing craft beer knowledge and culture in Izmir, particularly on the availability of the selection of distinct tastes and aromas. One participant noted:

For years we had a very limited selection of beer brands. (...) Although craft beer has a rather longer history abroad, it is very recent in Turkey. For instance, I always prefer pubs that serve local and craft brands, in search of novel flavours, when I am travelling abroad. It's very nice that we have such pubs and events in Izmir now. Many of my friends and I have been following such events and pubs.

\section{Another participant added:}

Craft beer is much tastier and more exciting than industrial brands. Any place, event or theme that includes craft beer would draw attention. These already exist in Izmir but I'm not sure whether they cooperate, or would be willing. Such a trail could be an attraction for Izmir and a tool for its promotion.

When asked about the structure and the formation of the craft beer trail as a tangible tourist product, the respondents stressed the fact that, in order to attract visitors from outside the city, the trail must integrate the local culture of Izmir, have a clear transportation schedule, preferably a mobile app. Although not in the initial interview form, a majority of participants added the need for a tour that includes accommodation:

Such an extensive trail including numerous visits, pub crawls and tastings would better include mass transportation and overnight options to prevent unwanted results and fatigue.

As for the professionals, the homebrewers' main concern was the inclusion of their non-commercial product in tastings, due to legal regulations. They expressed a unanimous willingness to participate as producers, should the situation is regulated, such as it is at the festival. Some homebrewers expressed an intent to become commercial producers. Regardless, they stated they would participate in such a trail as a visitor, in order to broaden their vision and experience in craft beer, or simply "to have a good time about a hobby they are passionate about". A recurring theme turned out to be the proposal of periodic events, such as a non-commercial tasting contest of homebrewed beers, as a means to sustain the demand for the trail:

The potential trail goers would be appropriate judges of homebrewing in my opinion, since these people already show a keen interest and motivation for craft beer.

Homebrewers especially expressed the importance of the promotion of the trail, but noticed eventual legal and cultural obstacles that should be taken into consideration. Lastly, they added the trail would increase the interest in craft brewing, and the number of craft brewers, eventually growing the gastronomical wealth, and naturally the number of visitors of Izmir:

As we see at the festival, beer and food pairing is a very exciting new venue of interest, which would certainly attract demand, as is the case in wine tourism. The trail would better include such activities.

The commercial craft beer producers are, Feliz Kolpa (Izmir), Pablo and Gara Guzu (Muğla), Red Tower (Antalya), Z1kkımm (Istanbul) and Graf (gypsy, with no constant location). The single Izmir craft beer brand Feliz Kulpa (the name of the producer is, jokingly, Feliz Kolpa) will be central to the trail and will be discussed later.

The craft brewers mentioned that craft beer trails are already main factors of attraction in certain countries:

Craft beer has a history of centuries in Europe and the USA. These countries offer specialised tours centred on craft beer, with well-established promotional efforts and abstract contribution to the country's tourism. We started rather late; however, our cuisine is very well suited to accompany distinct craft beer flavours. The number of craft brewers is slowly growing. Also, Turkish beer consumers who were limited by the narrow selection of industrially and mass-produced beer for decades have started to demand these new flavours, which is exciting. The introduction of such a trail in Turkey would certainly spark an interest in other cities, especially in Istanbul, Muğla and Antalya. For instance, the people who have tasted our beer during their vacation in different cities also expressed a wish to visit our brewery.

Craft brewers noticed the need to carefully regulate the events that would be included in the trail, such as tastings and promotion, since the laws on the production and promotion of alcoholic beverages must be observed. The majority of craft brewers also warned about the careful planning of competition and cooperation among the elements of the craft beer trail and an emphasis on mutual benefit and synergy, in order for the continuity of the trail.

The beer expert interviewed at the festival is a prominent expert in beer, and other alcoholic beverages, as well as overall gastronomy with a 20 year experience in the related fields. He emphasised the historic importance of beer in Turkey, as well as numerous beer types that have been produced. He expressed the versatility of beer, more than any other type of alcoholic beverages, with mostly unexplored multitude of complex flavours, as well as its suitability with the Turkish cuisine, which makes food and beer pairings very exciting:

Beer has a history of more than ten thousand years in Anatolia. However, we have started to explore the richness offered by beer very recently. This is both exciting and unfortunate, since the agricultural efforts, 
and ultimately food, have long been closely linked with beer production on this land. People around me are increasingly excited to sample and explore new flavours and new experiences. (...) Such a trail would be invaluable for the promotion of Turkey and Izmir. There are a lot of such examples abroad. (...) We also wish to develop the craft beer trend and rejuvenate our beer culture. There are also associations that include producers of craft beer. Such a trail is important in bringing craft producers and consumers together. To develop such a trail, in my opinion, producers and pubs should be very well coordinated, with effective and open lines of communication, so that end consumers receive correct information. The local government has an important role to play at this point, especially on promotion and permits.

Regarding the interviews with the stops, the findings will be evaluated within the proposed model.

\subsection{Izmir Craft Beer Trail: A Model Proposal}

As the result of the analysis, one craft beer producer and six other stops that could be included in the proposed craft beer trail have been determined, and shown on Figure 1 below:

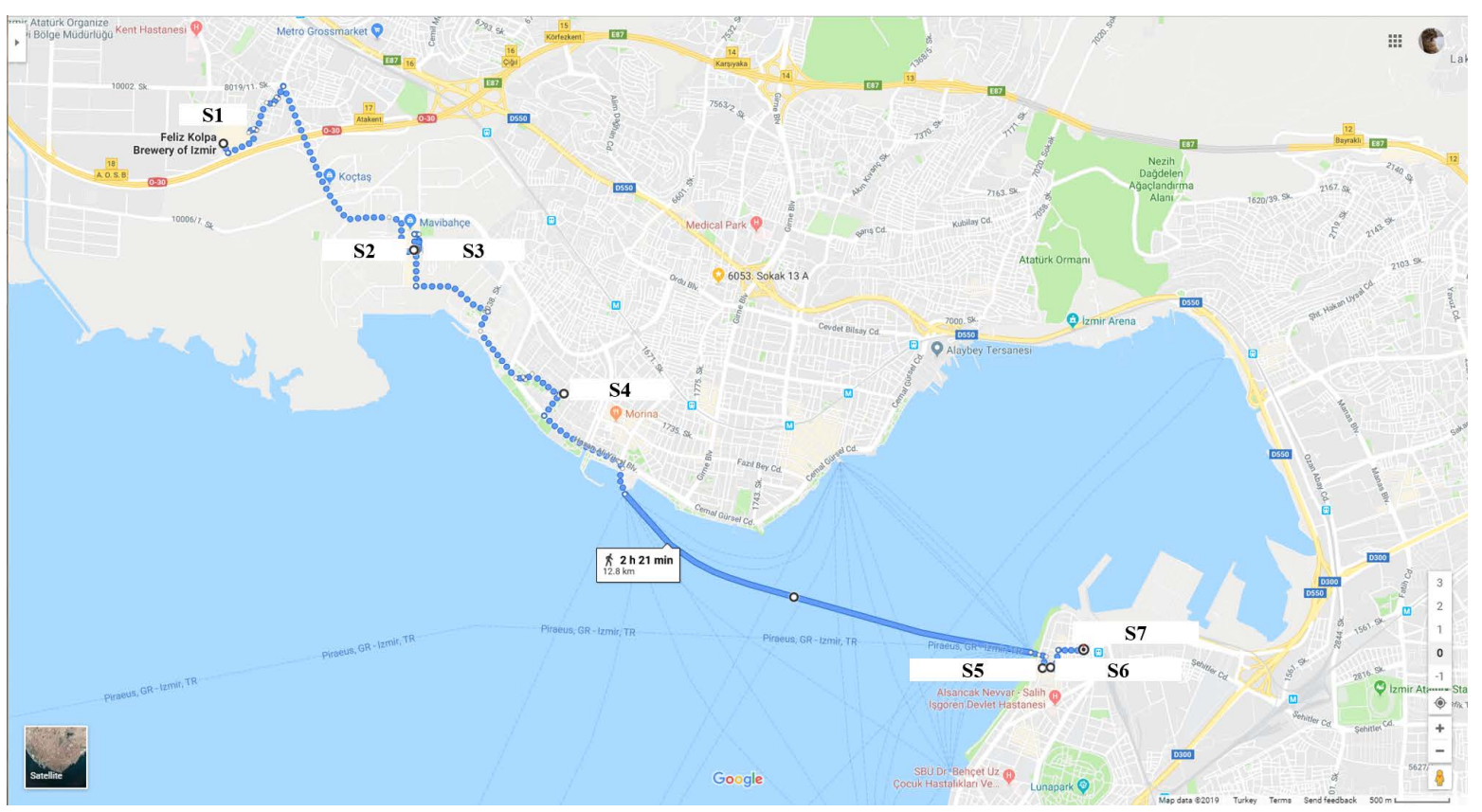

Figure 1. Izmir Craft Beer Trail 
The trail, $12.8 \mathrm{~km}$ long in total, physically starts at S2 \& S3, which are located in one of the largest open-air malls in Izmir, in the Mavişehir quarters. Reaching S4 is considerably convenient, via the light rail system. A short walk connects to the ferry terminal that leads to the pedestrian street in Alsancak, the main entertainment centre of the city, where the rest of the stops lie. Alsancak also offers an abundance of accommodation choices, convenient for the end of a day long beer trail and pub crawl. The venue for the two beer-themed events is marked with an A. During the festivals the trail can easily be modified thanks to the efficient public transportation system.

S1: The Feliz Kolpa Brewery is presently the single craft brewery of Izmir. It is not open to public visitation; however, the brewery's importance and guidance for the trail makes it the symbolic start of the trail. The other stops have been chosen on the criteria of serving the local beer brand of Izmir, along with other national craft brands. During the interview with the brewmaster, the brand expressed a strong willingness to coordinate (or manage) the proposed trail as well as a wish for increased competition and cooperation.

We would love to have more craft producers in Izmir. I believe the quality of Izmir's beer and gastronomy as a whole would benefit from increased sharing of knowledge and expertise as a result. (Such a) route seems feasible and mutually beneficial but it should be carefully planned and coordinated, with special care on legal issues.

The brand is particularly important as an ingredient of local culture and cuisine and it is reflected in their choice of names: Smyrn'ale carries the previous name of Izmir (Smyrna), Urla'Weiss carries the name of a coastal town (Urla) and Asf'ale'ya is a word play of local dialect. The flavours are also claimed to complement the Mediterranean cuisine of Izmir (during Brewstival, a Feliz Kulpa beer was paired with a local mixed herb plate).

S2: This is a pizzeria that combines Napolitan style pizza with local ingredients of Izmir such as local herbs, cheese, vegetables and olive oil. The restaurant already offers pairings of pizza and national craft beers and expressed a potential of becoming the hub for local beer and food pairings and workshops.

We serve local craft beer varieties and this is important for our guests to choose us. Many of our guests indicate that craft beer flavours complement our pizzas perfectly. We may consider including other local food items, even so for special occasions of pairing.

S3: This is a pub with a very wide selection of national and imported craft beer brands and other alcoholic beverages, accompanied with live jazz music. The pub is especially chosen on the basis of the wide segment of clientele and menu. Its inclusion may also generate a wider word-of-mouth for the trail. Its placement in the trail is also strategically important to offer recreational and musical relief after the pizzeria visit.

S4: This is a bar / restaurant serving a very wide selection of local, national and international beers as well as snacks and main courses. The service personnel offer precise advice about the beers on the menu and food pairings. The bar has another branch in Alsancak (S7).

S5: This is a casual bar, in the heart of the entertainment centre of Izmir, placed right after the ferry ride of the trail. While offering a generous selection of national craft beer brands, the bar is also famous for its house-recipe local aperitifs and snacks, which complement craft beer flavours. The bar expressed a further willingness to experiment with new food items as a means to emphasise food and beer pairings.

S6 / S7: This is a landmark bar for Izmir, having two (interchangeable) locations in close proximity in Alsancak (8 in total spread around Turkey), promoting backpacking culture. The bar offers a wide selection of national and international beers and food items in a large, relaxed location.

\section{Conclusions and Recommendations}

This paper focused on a rather neglected type of beverage related special interest tourism and a (somewhat debated) niche in the overall market, craft beer tourism. After reviewing the literature on (general) beer and craft beer tourism, as well as successful and failed examples around the world, Izmir, as the research field was studied. Although boasting a vibrant nightlife, an accommodating social structure, two large beer factories and two large annual beer related festivals, there is room to develop craft beer-oriented tourism activities, and more specifically, a craft beer trail model has been proposed.

The trail stretches along the city centre, located around the Izmir Bay, and main points of interest in terms of (possible) craft beer tourism. It encompasses the sole commercial craft beer producer and pubs and restaurants that serve it, along with other national \& international craft beer brands and accompanying food. The trail would also be modified to include beer festivals in their respective dates. As a result, the trail offers the potential of a complete craft beer experience that includes the tasting and appreciation of local craft beers, pairings of local food, landmark pubs, restaurants and events. Furthermore, the trail is proposed to embrace and promote the natural and cultural landscape, social life, craft beer related and general cultural heritage and overall tourism attraction of Izmir, ultimately branding the city as a prominent craft beer destination. Integration of local food, culture, landscape, daily life and transportation, stories and urban landmarks into the trail is deemed essential as these are supporting elements of the attraction of potential craft beer tourism, offering a stronger sense of place and a more memorable and complete tourist experience. 
During the research, an almost uniform positive approach and a willingness to participate in the supposed craft beer trail have been demonstrated by the participants of interviews. The reviewed stops of the trail, as well as craft beer producers have all expressed an already willingness to collaborate and cooperate to further share experience and technical knowledge in terms of craft beer production and service, and tourism. The situation could be interpreted as a strong sign of a need for, and a higher chance of success of the proposed craft beer trail. Despite the overall positive approach, the (in-development) sole brewpub of Izmir, which could obviously be a focal point, has expressed refusal to participate in the research. The research underwent no time restraints as it lasted throughout the year to offer sufficient time to research the beer festival and potential stops, with the exception of "Oktoberfest", which will be held at a future date. Should the craft beer producer be one day open to public visitation, this will greatly benefit the trail.

The participants have expressed the need to integrate accommodation and the trail takes place where a large number of bed capacity is located. Also, public transportation is considered effective, which should prevent driving under the influence of alcohol. A last important point made was legal restraints on promotion of alcohol related products and events. It is advised that the management of the craft beer trail include legal counselling. There are some non-profit organisations that are candidates for the management of the trail, including the "independent Turkish beer producers", "Turkish beer collectors club", "homebrewers association", as well as separate working groups around specific brands. It is also advisable to form a singular working group to handle the legal issues, transportation, accommodation, web and mobile development, route management, promotion and related issues for the Izmir craft beer trail. The management group could potentially be spearheaded by the sole craft beer producer and should include representatives of each stop, representatives from Ministry of Culture and Tourism, Turkish Hoteliers Federation and Association of Turkish Travel Agencies, as well as marketing and legal consultants.

The development of craft beer tourism in the city is meant to offer product diversification as well as a means to increase occupancy rates and ease tourism congestion. Utilisation of local resources, such as craft beer production, service and accommodation should also help reduce leakages and increase multiplier effect for the city. Further research could be conducted for relevant and/or similar types of tourism products or destinations.

\section{REFERENCES}

[1] T. Acitelli. The Audacity of Hops: The History of America's
Craft Beer Revolution, Chicago Review Press, Chicago, 2013.

[2] R. I. Allison, K. P. Uhl. Influence of beer brand identification on taste perception, Journal of Marketing Research, Vol.1, No.3, 36-39, 1964.

[3] S. Almonacid, A. Nájera, M. Young, R. Simpson, C. Acevedo. Comparative study of stout beer batch fermentation using free and microencapsulated yeasts, Food and Bioprocess Technology, Vol. 5, No.2, 750-758, 2012.

[4] A. D. Alonso. Opportunities and Challenges in the Development of Micro-Brewing and Beer Tourism: A Preliminary Study from Alabama, Tourism Planning \& Development, Vol.8, No.4, 415-431, 2011.

[5] B. Aquilani, T. Laureti, S. Poponi, L. Secondi. Beer choice and consumption determinants when craft beers are tasted: An exploratory study of consumer preferences, Food Quality and Preference, Vol. 41, 214-224, 2015.

[6] B. Ascher. Global Beer: The Road to Monopoly Table of Contents, The American Antitrust Institute, USA, 2012.

[7] C. Bamforth. Beer Tap into the Art and Science of Brewing (2 ed.). 198 Madison Avenue, Oxford University Press, New York, 2003.

[8] A. Biancolillo, R. Bucci, A. L. Magrì, A. D. Magrì, F. Marini. Data-fusion for multiplatform characterization of an Italian craft beer aimed at its authentication, Analytica Chimica Acta, Vol. 820, 23-31, 2014.

[9] Brewers Association. Brewers Association Revises Craft Brewer Definition. Retrieved from Brewers Association, 2014, Online available from https://www.brewbound.com/n ews/brewers-association-revises-craft-brewer-definition.

[10] C. Brown. The Difference between a Craft Beer and a Micro Brew Beer, 2016. Retrieved 12.03.2018, Online available from https://delishably.com/beverages/The-Difference-Bet ween-a-Craft-Beer-and-a-Micro-Brew-Beer

[11] G. Brunori, A. Rossi. Synergy and Coherence through Collective Action: Some Insights from Wine Routes in Tuscany, Sociologia Ruralis, Vol. 40, 409-424, 2000.

[12] CAMRA. Statistics. Retrieved from Campaign for Real Ale, 2014, Online available from http://www.camra.org.uk/realale-market-statistics.

[13] G. Caporale, E. Monteleone. Influence of information about manufacturing process on beer acceptability, Food Quality and Preference, Vol. 15, No. 3, 271-278, 2004.

[14] D. Y. Choi, M. H. Stack. The all-American beer: A case of inferior standard (taste) prevailing? Business Horizons, Vol. 48, No. 1, 79-86, 2005.

[15] E. K. Clemons, G. G. Gao, L. M. Hitt. When online reviews meet hyper differentiation: A study of the craft beer industry, Journal of Management Information Systems, Vol. 23, No. 2, 149-171, 2006.

[16] M. Deneault. Acquiring a taste for cuisine tourism: A product development strategy. Canadian Tourism Commission, Ottawa, 2002.

[17] A. Dunn, M. Wickham. Craft brewery tourism best-practices: A research agenda. Annals of Tourism Research, Vol. 56, 
140-142, 2016.

[18] K. G. Elginza, C. H. Tremblay, V. J. Tremblay. Craft Beer in the United States: History, Numbers, and Geography. Journal of Wine Economics, Vol. 10, No. 3, 242-274, 2015.

[19] Euromonitor International. Alcoholic Drinks Global Industry Overview, Retrieved from Euromonitor International, 2018, www.euromonitor.com

[20] W. Flack. American Microbreweries and Neolocalism: "Ale-ing" for a "Sense of Place". Journal of Cultural Geography, Vol. 16, No. 2, 37-53, 1997.

[21] J. L. Francioni. Beer Tourism: A Visitor and Motivational Profile for North Carolina Craft Breweries. Master's Thesis. Greensboro, the Faculty of the Graduate School at the University of North Carolina at Greensboro, USA. 2012.

[22] R. Gaugler. Alternative Paradigms for Commercializing Biopesticides, Phytoparasitica, Vol. 25, No. 3, 179-182, 1997.

[23] V. Giovenzana, R. Beghi, R. Guidetti. Rapid evaluation of craft beer quality during fermentation process by vis/NIR spectroscopy, Journal of Food Engineering, Vol. 142, 80-86, 2014.

[24] R. Gulati. Alliances and networks, Strategic Management, Vol. 19, 293-317, 1998.

[25] C. Hall. Small Firms and Wine and Food Tourism in New Zealand: Issues of collaboration, clusters and lifestyles. In R. Thomas (Ed.), Small Firms in Tourism: International Perspectives (167-181). Elsevier, Oxford, 2004.

[26] C. M. Hall. Local initiatives for local regional development: The role of food, wine and tourism. In E. Arola, J. Kärkkäinen, \& M. Siitari (Ed.), Tourism and well-being. The 2nd Tourism Industry and Education Symposium (47-63). Jyväskylä, Jyväskylä Polytechnic, Finland, 2002.

[27] C. M. Hall, L. Sharples. The consumption of experiences or the experience of consumption? An introduction to the tourism of taste. In C. M. Hall, L. Sharples, R. Mitchell, N. Macionis, \& B. Cambourne (Eds.), Food tourism around the world: Development, management and markets (1-24), Butterworth Heinemann, Oxford, 2003.

[28] E. Janzen. A Brief History of Beer Tourism in America. Retrieved from Fantasy Travel Week, 2015, Online available from www.foodrepublic.com/2015/02/10/a-briefhistory-of-beer-tourism-in-america/

[29] J. Kleban, I. Nickerson. To brew, or not to brew - That is the question: An analysis of competitive forces in the craft brew industry, Journal of the International Academy for Case Studies, Vol. 18, No. 3, 59-82, 2012.

[30] D. Lachenmeier. Rapid quality control of spirit drinks and beer using multivariate data analysis of Fourier transform infrared spectra, Food Chemistry, Vol. 101, No. 2, 825-832, 2007.

[31] L. Lee, S. Frederick, D. Ariely. Try it, you'll like it: The influence of expectation, consumption, and revelation on preferences for beer. Psychological Science, Vol. 17, No. 12, 1054-1058, 2006

[32] F. Liu, Y. Jiang, Y. He. Variable selection in visible/near infrared spectra for linear and nonlinear calibrations: a case study to determine soluble solids content of beer, Analytica Chimica Acta, Vol. 635, No. 1, 45-52, 2009.

[33] G. McBoyle. Green tourism and Scottish distilleries. Tourism Management, Vol. 17, No. 4, 255-263, 1996.

[34] G. McLeod, K. Clelland, H.Tapp, E. Kemsley, R. Wilson, G. Poulter, C. Hewitt. A comparison of variate pre-selection methods for use in partial least squares regression: A case study on NIR spectroscopy applied to +monitoring beer fermentation, Journal of Food Engineering, Vol. 90, No. 2, 300-307, 2009.

[35] O. Mejlholm, M. Martens. Beer identity in Denmark. Food Quality and Preference, Vol. 17, 108-115, 2006.

[36] Murray, A., \& Kline, C. (). Rural tourism and the craft beer experience: factors influencing brand loyalty in rural North Carolina, USA, Journal of Sustainable Tourism, Vol. 23, No. (8-9), 1198-1216, 2015.

[37] G. Oates. Travel on Tap: The Rise of Craft Beer Tourism, 2016, Online available from https://skift.com/2016/07/28/th e-rise-of-craft-beer-tourism/

[38] G. Oliver. Craft brewing. In the Oxford Companion to Beer, Oxford University Press, Oxford, UK, 2011.

[39] K. Pavlovich. The Evolution and Transformation of a Tourism Destination Network: The Waitomo Caves, New Zealand. Tourism Management, Vol. 24, 203-216, 2003.

[40] R. Plummer, D. Telfer, A. Hashimoto. The Rise and Fall of the Waterloo-Wellington Ale Trail: A Study of Collaboration within the Tourism Industry. Current Issues in Tourism, Vol. 9, No.3, 191-205. 2006, Online available from https://doi.org/10.2167/cit/194.0

[41] R. Plummer, D. Telfer, A. Hashimoto, R. Summers. Beer tourism in Canada along the Waterloo-Wellington Ale Trail. Tourism Management, Vol. 26, No. 3, 447-458, 2005.

[42] M. Robinson, M. Novelli. Niche tourism: An introduction. In M. Robinson, \& M. Novelli, Niche Tourism $(1-11)$, Elsevier Butterworth-Heinemann, Burlington, MA, 2005.

[43] C. M. Rogerson. Craft beer, tourism and local development in South Africa. In C. M. Hall, \& S. Gössling (Eds.), Food Tourism and Regional Development: Networks, products and trajectories (227-241), 2016.

[44] C. M. Rogerson, K. J. Collins. Developing beer tourism in South Africa: international perspectives, African Journal of Hospitality, Tourism and Leisure, Vol. 4, No. 1, 2015.

[45] S. M. Schnell, J. F. Reese. Microbreweries as Tools of Local Identity, Journal of Cultural Geography, Vol. 21, No. 1, 45-69, 2003.

[46] C. Sester, C. Dacremont, O. Deroy, D. Valentin. Investigating consumers' representations of beers through a free association task: A comparison between packaging and blind conditions, Food Quality and Preference, Vol. 28, No.2, 475-483, 2013.

[47] S. Sohrabvandi, A. M. Mortazavian, K. Rezaei. Health-related aspects of beer: A review, International Journal of Food Properties, Vol. 15, No. 2, 350-373, 2012.

[48] D. Telfer. Strategic Alliances along the Niagara Wine Route, Tourism Management, Vol, 22, 21-30, 2001. 
[49] D. J. Telfer. Tastes of Niagara: Building strategic alliances between tourism and agriculture, International Journal of Hospitality and Tourism Administration, Vol. 1, No. 1, 7188, 2000.

[50] The Barth-Haas Group. The Barth Report 2017/2018. Retrieved from The Barth-Haas Group: Online available from www.barthhaasgroup.com/en/media-library/reports

[51] TR Ministry of Culture and Tourism. Tourism Statistics, 2019, Online available from http://yigm.ktb.gov.tr/TR-9851 /turizm-istatistikleri.html

[52] UN \& UNWTO. International Recommendations for Tourism Statistics 2008. Retrieved from ISBN 978-92-1-161521-0, United Nations Department of Economic and Social Affairs, New York, 2010
[53] M. Watkins, B. Bell. The experience of forming business relationships in tourism, International Journal of Tourism Research, Vol. 4, 15-28, 2002.

[54] T. Wesson, L. De Figueiredo. The Importance of Focus to Market Entrants: A Study of Microbrewery Performance. Journal of Business Venturing, Vol. 16, 377-403, 2001.

[55] C. A. Wright, C. M. Bruhnc, H. Heymann, C. W. Bamforth. Beer and wine consumers' perceptions of the nutritional value of alcoholic and nonalcoholic beverages. Institute of Food Technologists, Vol. 73, No.1, 8-11, 2008.

[56] G. Zong, X.-D. Zhao. Comparison between the Munich Oktoberfest and the Qingdao international beer festival, Tourism Tribune, Vol. 28, No. 5, 72-79, 2013. 